\title{
GENITAL PROLAPSE IN WOMEN OF REPRODUCTIVE AGE GROUP IN A RURAL COMMUNITY OF BANGLADESH
}

\author{
KISHWARA $\mathrm{S}^{1}$, TANIRA $\mathrm{S}^{2}$, OMAR $\mathrm{E}^{3}$, BEGUM K ${ }^{4}$
}

\begin{abstract}
:
Context: Genital prolapse is a very common gynaecological disorder in Bangladesh. But women do not admit this problem due to shame, ignorance, social taboo and insolvency. The rural scenario is much more disastrous. The aim of the present study was to find out the prevalence of genital prolapse and its correlation with sociodemographic status in a rural area of Bangladesh.

Methods: A cross-sectional descriptive type of study was conducted at a village named Sharifbag of Dhamrai upazilla under Dhaka district from March to May in the year 1997. The total population of the village was 2605. All the married women of reproductive age (15-49 years) of that village were the study population. The sample size was estimated 200. They were interviewed based upon a semi-structured questionnaire set in Bengali language. After collection, data were compiled, summarized and analyzed to get the results.

Results: Among 200 women, only 9 were reported to have the complaints of a genital prolapse. $54 \%$ of women were in 15-29 years age group, while 46\% belonged to $30-49$ years age group. Most of the women were married (86\%) and having no education (78.5\%). The present study revealed that respondents' age had no association with the incidence of genital prolapse $(p>0.05)$. But strong association was found between number of child and genital polapse $(p<0.05)$. Besides, respondents' monthly income was also strongly associated with incidence of genital polapse $(p<0.05)$. More incidence of genital polapse was found in women having parity $>6$ and 5-6 and hailing from a very low income group.
\end{abstract}

Key words: Genital prolapse, sociodemographic status, rural community, reproductive health.

J Dhaka Med Coll. 2010; 19(2) : 118-121.

\section{Introduction:}

The reproductive health profile of women in developing countries like Bangladesh is burdened from diseases and injury related to sexuality and child bearing. The scenario is more disastrous in rural communities. Despite some advancement in family planning and fertility control, overall reproductive health status is still critically lagging behind ${ }^{1}$. The word 'prolapse' is literally derived from 'prolapsus', which means falling down or sinking in of a part or viscus. In genital prolapse, the patient usually presents herself with the complaints that her womb has come down or something coming out through the vagina, along with backache, frequency of micturition, loss of bladder control, difficulty in emptying bowel ${ }^{2}$. So, it interferes with quality of life as the patient feels discomfort during walking or sitting and faces limitations in physical activities and problems with bladder and/or bowel. There is a scarcity of information on genital prolapse in our country and research works based on that are very few in number. While concerns relating to genital prolapse are important to women's health and social well being, none of the available health facilities is particularly attuned to addressing the needs ${ }^{3}$. Therefore, developing health care services taking women's explanatory models into

1. Dr. Segupta Kishwara, Assistant Professor, Department of Anatomy, Dhaka Medical College, Dhaka.

2. Dr. Shaorin Tanira, Coordinator (Health), MCH-FP Clinic, Manabik Shahajya Sangstha (MSS), Dhaka.

3. Dr. Eliza Omar, Assistant Professor, Department of Pharmacology, Shaheed Suhrawardy Medical College, Dhaka.

4. Dr. Khadiza Begum, Ex-Professor \& Head, Department of Maternal and Child Health \& Family Planning, National Institute of Preventive and Social Medicine (NIPSOM), Dhaka.

Correspondence: Dr. Segupta Kishwara, Assistant Professor, Department of Anatomy, Dhaka Medical College, Dhaka, Cell Phone: +8801713037269 
consideration could be of importance for providing a healthier, happier and productive life for women. Keeping that issue in mind, different perspective of genital prolapse is to be brought into light, as beyond being a health related problem, it has got some social and psychological disruptions as well ${ }^{4}$. The present study was designed to find out the prevalence of genital prolapse and its correlation with sociodemographic status in a rural area of Bangladesh. The occurrence of prolapse and its complications have broad implications not only for women themselves and their partners, but also for those responsible for administering women's health programs and for training health care providers to meet this rapidly escalating demand.

\section{Methods:}

A cross-sectional descriptive type of study was conducted at a village named Sharifbag of Dhamrai upazilla under Dhaka district from March to May in the year 1997. The area was chosen due to well communication, large population including $48.8 \%$ women, and its popularity as a public health research site. The total population of the village was 2605 . All the married women of reproductive age (15-49 years) of that village were the study population. The sample size was estimated 200. They were interviewed based upon a semi-structured questionnaire set in Bengali language. At first, a rapport was built up with each participant. After taking the verbal informed consent from her and maintaining adequate privacy, she was interviewed. After collection, data were compiled, summarized and analyzed to get the results.

The present study was approved by the Research Protocol Review Committee of National Institute of Preventive and Social Medicine (NIPSOM), Dhaka.

\section{Results:}

Among 200 women, only 9 were reported to have the complaints of a genital prolapse. The results of the present study are shown in tabulated forms (Table-I, II, III \& IV).
Table-I

Sociodemographic features of the respondents of the study $(n=200)$

\begin{tabular}{rcc}
\hline $\begin{array}{l}\text { Age limit } \\
\text { in years }\end{array}$ & $\begin{array}{c}\text { No. of } \\
\text { respondents }\end{array}$ & Percentage \\
\hline $15-29$ & 108 & 54 \\
$30-49$ & 92 & 46
\end{tabular}

Educational status

$\begin{array}{lcc}\text { Illiterate } & 89 & 44.5 \\ \text { Can give signature } & 68 & 34 \\ \text { Primary } & 40 & 20 \\ \text { S. S. C. } & 02 & 01 \\ \text { H. S. C. and above } & 01 & 0.05\end{array}$

Marital status

$\begin{array}{lcc}\text { Living with husband } & 167 & 83.5 \\ \text { Divorced } & 02 & 01 \\ \text { Husband living abroad } & 25 & 12.5 \\ \text { Widow } & 06 & 03\end{array}$

Parity of women

$\begin{array}{lcc}0 & 25 & 12.5 \\ 1-2 & 83 & 41.5 \\ 3-4 & 62 & 31 \\ 5-6 & 22 & 11 \\ >6 & 08 & 04\end{array}$

Monthly family income (in Taka)

\begin{tabular}{lcc}
$\leq 4000$ & 141 & 70.5 \\
$4001-8000$ & 54 & 27 \\
$>8001$ & 05 & 2.5 \\
\hline
\end{tabular}

Table-II

Distribution of respondents by age with genital prolapse

\begin{tabular}{lccc}
\hline Age in years & \multicolumn{2}{c}{ Genital prolapse } & Total \\
\cline { 2 - 3 } & Yes (\%) & No (\%) & \\
\hline $15-29$ & $04(3.7)$ & $104(96.3)$ & 108 \\
$30-49$ & $05(5.4)$ & $87(94.6)$ & 92 \\
\hline Total & $09(4.5)$ & $191(95.5)$ & 200 \\
\hline Here, $\mathrm{X}^{2}=0.2$ & $\mathrm{df}=1$ & $\mathrm{p}>0.05$ & Not \\
& & & \multicolumn{3}{c}{ significant }
\end{tabular}


Table-III

Distribution of respondents by parity with genital prolapse

\begin{tabular}{lccc}
\hline Parity & \multicolumn{2}{c}{ Genital prolapse } & Total \\
& Yes $(\%)$ & No $(\%)$ & \\
\hline $1-2$ & $01(1.2)$ & $82(98.8)$ & 83 \\
$3-4$ & $02(3.2)$ & $60(96.8)$ & 62 \\
$5-6$ & $04(18.2)$ & $18(81.8)$ & 22 \\
$>6$ & $02(25)$ & $06(75)$ & 08 \\
\hline Total & 09 & 166 & $175^{*}$ \\
\hline
\end{tabular}

\begin{tabular}{llll}
\hline Here, $\mathrm{X}^{2}=17.7$ & $\mathrm{df}=3$ & $\mathrm{p}<0.05$ & Significant
\end{tabular}

*The rest 25 respondents were primary infertile and/or pregnant at that time.

Table-IV

Distribution of respondents by monthly family income with genital prolapse

\begin{tabular}{|c|c|c|c|}
\hline \multirow{2}{*}{$\begin{array}{l}\text { Monthly family } \\
\text { income }\end{array}$} & \multicolumn{2}{|c|}{ Genital prolapse } & \multirow[t]{2}{*}{ Tota } \\
\hline & Yes (\%) & No (\%) & \\
\hline$\leq 4000$ & $08(5.7)$ & $133(94.3)$ & 141 \\
\hline $4001-8000$ & - & $54(100)$ & 54 \\
\hline$>8001$ & $01(20)$ & $04(80)$ & 05 \\
\hline Total & 09 (4.5) & $191(95.5)$ & 200 \\
\hline
\end{tabular}

Here, $\mathrm{X}^{2}=6.3 \quad \mathrm{df}=2 \quad \mathrm{p}<0.05 \quad$ Significant

The present study revealed that respondents' age had no association with the incidence of genital prolapse $(p>0.05)$. But strong association was found between number of child and genital prolapse $(p<0.05)$. It showed the more incidence of genital prolapse in women having parity $>6$ and $5-6$. It also revealed that respondents' monthly income was strongly associated with incidence of genital prolapse $(\mathrm{p}<0.05)$. The incidence was found more in women who had a very low economic status.

\section{Discussion:}

Begum and Tahera (1992) ${ }^{4}$ stated that the genital prolapse is the $4^{\text {th }}$ commonest gynaecological disorder in Bangladesh. Among the respondents of the present study, 9.1\% had genital prolapse. In her study, Begum (1995) ${ }^{5}$ found $13.89 \%$ women suffering from genital prolapse. The present study showed no significant association of age with genital prolapse where $55.6 \%$ cases (5 out of 9 ) of genital prolapse belonged to $30-49$ years age group and $44.4 \%$ were in $15-29$ years age group. Akhter (1996) ${ }^{6}$ found that $74 \%$ of patients were in $>40$ years age group. But Begum $(1995)^{5}$ found that $90 \%$ of cases belonged to $>50$ years age group, as she did her research only on postmenopausal women. Sen et al. (1984) ${ }^{7}$ found that $32.5 \%$ of women, who had genital prolapse, were in $30-40$ years age group. Ambiye and Chandni $(1983)^{8}$ also found the highest prevalence $(47 \%)$ in $31-40$ years age group. The present study revealed a strong association between grand multiparity and prevalence of genital prolapse. The result is quite consistent with the findings of Akhter (1996) ${ }^{6}$, Begum $(1995)^{5}$, Begum and Tahera (1992) ${ }^{4}$ and Ambiye and Chandni $(1983)^{8}$, Paul and Malik (1984) ${ }^{9}$. They found the highest prevalence in parity group 5-9, >7, 5-9, 3-4, >5 respectively. Genital prolapse may be manifested along with backache, frequency of micturition, sometimes loss of bladder control, difficulty in emptying bowel or rectocele $e^{2,4,9}$. Most of these phenomena are related to grand multiparity, complications of home delivery and to some extent, history of unsafe abortion ${ }^{10}$. Low socioeconomic environment acts as a stimulatory factor in morbidities related to reproductive heath ${ }^{11}$. The present study also showed the correlation, as $88.9 \%$ of patients (8 out of 9) of genital prolapse were of very low economic status. Akhter $(1996)^{6}$ found the highest prevalence $(68.57 \%)$ in women with low socioeconomic background. Begum and Tahera $(1992)^{4}$ also stated that women who encountered genital prolapse were the representatives of an uneducated and poor social set up. The limitations of the present study include time constraint, selecting site which may not necessarily represent the actual scenario of Bangladesh and lack of per vaginal examination which was very important for confirmation of the diagnosis.

\section{Conclusion:}

Through this research, we ultimately hope to heighten the attention of health care providers and program managers to the high prevalence of genital prolapse especially in rural areas and the provision of improved access to care, availability of well-trained staff and high rates 
of hospital deliveries both in public and private sectors.

\section{Acknowledgement:}

We express our gratitude to all the participants of the study and the local government representative and leaders of the village for their cooperation.

\section{References:}

1. Reproductive health and gender: a working paper. Dhaka: UNFPA. 1996; p. 15.

2. Dutta DC. Displacement of the uterus. In: Text book of gynaecology including contraception. $5^{\text {th }}$ ed. Kolkata: New Central Book Agency; 2009. p. 193-219.

3. Akhter HH, Khan TF. Selected reproductive health elements and interventions. Dhaka: Bangladesh Institute of Research for Promotion of Essential and Reproductive Health and Technologies (BIRPERHT). 1997. p. 12

4. Begum A, Tahera D. Genital prolapse: host and environmental determinants amongst Bangladeshi women. [editorial]. Bangladesh J Obstet Gynaecol. 1992; 7(1): 1-8.
5. Begum A. Study on prevalence of obstetric related gynaecological conditions amongst post menopausal women. [dissertation]. Dhaka: NIPSOM, University of Dhaka. 1995. p. 19-41.

6. Akhter K. Clinical profile and management of genital prolapse. [thesis]. Dhaka. IPGMR, University of Dhaka. 1996. p. 95-8.

7. Sen S, Mukherjee KK, Chakraborty BK. Genital prolapse: J Indian Med Assoc. 1984; 82: 159-61.

8. Ambiye VR, Chandni MA. Genital prolapse associated with pregnancy. J Obstet Gynecol India. 1983; 33: 230-3.

9. Paul MN, Malik N. Urodynamic profile in cases of genital prolapse. J Obstet Gynecol India. 1984; 34: 428-32.

10. Luber KM, Boero S, Choe JY. The demographics of pelvic floor disorders: current observations and future projections. Am J Obstet Gynecol 2001; 184(7): 1496-1501.

11. Ross JL, Laston SL, Pelto PJ, Muna L. Exploring explanatory models of women's reproductive health in rural Bangladesh. Culture, Health \& Sexuality. 2002; 4(2): 173-90. 